\title{
KEPADATAN (MAN BITING RATE) NYAMUK ANOPHELES DI DESA RANOKETANG TUA, KECAMATAN AMURANG KABUPATEN MINAHASA SELATAN
}

\author{
Joy V.I Sambuaga ${ }^{\text {a) }}$, Risman S. Duka ${ }^{\text {a) }}$, Djani Hermanus ${ }^{\text {b) }}$ \\ a) Jurusan Kesehatan Lingkungan Poltekkes Kemenkes Manado, Indonesia \\ ${ }^{b)}$ Dinas Kesehatan Provinsi Sulawesi Utara, Indonesia \\ E-mail : joysambuaga@yahoo.com
}

\begin{abstract}
Malaria is the most important tropical parasitic disease in the world, and is still a major health problem. South Minahasa Regency was ranked 4th in Malaria Morbidity Rate (API) in 2017. Ranoketang Tua Village was one of the highest cases of malaria, 61 cases, based on data from the 2017 health center. This study aimed to determine the diversity and density (Man Biting Rate) of Mosquitoes Anopheles in Ranoketang Tua Village, Amurang District, South Minahasa Regency. This research is a type of descriptive research. The samples in this study were Anopheles mosquitoes that were caught through the method of insider bait (UOD) and outsider bait (UOL) identified by the species and calculated the Man Bitting Rate (the number of Mosquitoes Biting per person per night). Research Results Found three species of Anopheles namely An. barbirostis, An. tesselatus and An. flavirostris. Density of Anopheles sp mosquitoes in Ranoketang Tua Village, namely An Mosquitoes. barbirostris MBR 49, An Mosquito. flavirostris MBR 3.75 and An Mosquito. tesselatus MBR 0.125. Suggestions to the public to use insecticide-treated mosquito nets, use mosquito coils or reppelant during sleep and wear long-sleeved clothing when doing outdoor activities at night. In order to avoid mosquito bites and reduce the population of Anopheles sp.
\end{abstract}

Keywords: Anopheles ; Malaria ; Diversity ; Species ; Density

\begin{abstract}
ABSTRAK
Malaria merupakan penyakit parasit tropis yang terpenting di dunia, dan masih menjadi masalah kesehatan utama. Kabupaten Minahasa Selatan menduduki peringkat ke 4 Angka Kesakitan Malaria (API) pada tahun 2017. Desa Ranoketang Tua salah satu yang tertinggi kasus penyakit malaria yakni 61 kasus, berdasarkan data puskesmas 2017. Penelitian ini bertujuan untuk mengetahui keragaman dan kepadatan (Man Biting Rate) Nyamuk Anopheles di Desa Ranoketang Tua Kecamatan Amurang Kabupaten Minahasa Selatan. Penelitian ini merupakan jenis penelitian deskriptif. Sampel dalam penelitian ini nyamuk Anopheles yang tertangkap melalui metode umpan orang dalam (UOD) dan umpan orang luar (UOL) yang diidentifikasi spesiesnya dan dihitung Man Bitting Rate (Jumlah Nyamuk Mengigit per orang per malam). Hasil Penelitian Ditemukan tiga spesies Anopheles yaitu An. barbirostis, An. tesselatus dan An. flavirostris. Kepadatan nyamuk Anopheles sp di Desa Ranoketang Tua, yaitu Nyamuk An. barbirostris MBR 49, Nyamuk An. flavirostris MBR 3,75 dan Nyamuk An. tesselatus MBR 0,125. Saran kepada masyarakat untuk menggunakan kelambu berisektisida, menggunakan obat nyamuk atau reppelant pada saat tidur dan menggunakan pakaian lengan panjang jika melakukan aktivitas di luar rumah pada malam hari.agar dapat terhindar dari gigitan nyamuk dan dapat mengurangi populasi dari nyamuk Anopheles sp.
\end{abstract}

Kata kunci: Anopheles, Malaria, Keragaman, Spesies, Kepadatan

\section{PENDAHULUAN}

Malaria dapat ditemukan mulai dari belahan bumi utara (Amerika Utara sampai Eropa dan Asia) ke belahan bumi selatan (Amerika Selatan); mulai dari daerah dengan ketinggian $2850 \mathrm{~m}$ sampai dengan daerah yang letaknya $400 \mathrm{~m}$ di bawah permukaan laut. Keadaan malaria di dunia saat ini diperkirakan terdapat 300-500 juta kasus malaria klinis/tahun dengan 1,5-2,7 juta kematian, terutama negara-negara benua Afrika. Risiko tinggi penularan malaria di Afrika dengan 
jumlah estimasi kasus pada tahun 2010 sekitar 174 kasus dengan estimasi kematian sebanyak 596.000 kasus (Arsin, 2012).

Sebanyak $90 \%$ kematian terjadi pada anak-anak dengan rasio 1: anak balita di Afrika meninggal karena malaria (Arsin, 2012).

Negara yang termasuk wilayah endemis malaria di Asia Tenggara adalah : Bangladesh, Bhutan, India, Indonesia, Maldives, Myanmar, Nepal, Srilanka, dan Thailand (Arsin, 2012). Menurut Survey Kesehatan Rumah Tangga Tahun 2001, terdapat 15 juta kasus malaria dengan 38.000 kematian setiap tahunnya. Dipekirakan $35 \%$ penduduk Indonesia tinggal didaerah yang beresiko tertular malaria. Dari 484 Kabupaten/Kota yang ada di Indonesia, 388 Kabupaten/Kota merupakan wilayah endemis malaria (Depkes RI, 2008).

Data Dinas Kesehatan Provinsi Sulawesi Utara (Annual Parasite Insidence) Malaria tahun 2017 adalah $0,72 \%$, bila di bandingkan dengan (API) Malaria pada tahun sebelumnya $0,74 \%$. Kabupaten Minahasa Selatan adalah salah satu Kabupaten yang Endemis Malaria, Kabupaten Minahasa Selatan menduduki peringkat ke 4 Angka Kesakitan Malaria (API) pada tahun 2017, yaitu 0,72 \%. (Provinsi Sulut, 2017). Desa Ranoketang Tua adalah salah satu yang tertinggi kasus penyakit malaria yakni 61 kasus, berdasarkan data puskesmas 2017.

Berdasarkan uraian permasalahan diatas dan data survei sementara yang pernah penulis lakukan, maka penulis tertarik untuk mengetahui Keragaman dan Kepadatan Nyamuk Anopheles di Desa Ranoketang Tua, Kecamatan Amurang Kabupaten Minahasa Selatan. Karena Desa tersebut merupakan desa yang memiliki kasus malaria yang cukup tinggi dan diperkirakan banyak tempat berkembang biak (breeding place) nyamuk Anopheles, karena sebagian besar atau sekitar $40 \%$ daerah tersebut terdiri dari rawa, perkebunan serta sawah dan kolam ikan yang tidak terawat.

Penyakit malaria awalnya di kenal sebagai penyakit akibat udara buruk (mala: buruk; aia: udara), sehingga penyakit ini sering terjadi di daerah rawa, karena banyaknya penduduk daerah pantai yang menderita gejala gejala malaria yaitu demam tinggi, menggigil, dan berkeringat (Santjaka, 2013).

Malaria adalah penyakit infeksi yang di sebabkan oleh parasit Plasmodium yang hidup dan berkembang biak dalam sel darah merah manusia. Penyakit ini secara alami ditularkan melalui gigitan nyamuk Anopheles betina (Depkes RI, 2008).

Gejala malaria terdiri dari beberapa serangan demam dengan interval tertentu (disebut parokisme), diselingi oleh suatu periode yang penderitanya bebas sama sekali dari demam disebut periode laten. Gejala yang khas tersebut biasanya ditemukan pada penderita non imun. Sebelum timbulnya demam, biasanya penderita merasa lemah, mengeluh sakit kepala, kehilangan nafsu makan, merasa mual, di ulu hati, atau muntah semua gejala awal ini disebut gejala prodormal (Arsin, 2012).

Plasmodium yang dapat menimbulkan penyakit ini ada 4 yaitu Plasmodium falciparum yang menyebabkan malaria tropika, Plasmodium vivax yang menyebabkan malaria tertiana, Plasmodium malariae yang menyebabkan malaria Quartana dan Plasmodium ovale menyebabkan malaria ovale (Santjaka, 2013).

Plasmodium, mempunyai dua fase perkembangan yaitu satu fase pada tubuh nyamuk (fase seksual) dan fase pada tubuh manusia (fase aseksual).

Tabel 1. Masa Inkubasi Penyakit Malaria

\begin{tabular}{lc}
\hline \multicolumn{1}{c}{ Plasmodium } & $\begin{array}{c}\text { Masa Inkubasi } \\
\text { (hari) }\end{array}$ \\
\hline Plasmodium falciparum & $9-14$ \\
Plasmodium vivax & $12-17$ \\
Plasmodium ovale & $16-18$ \\
Plasmodium malariae & $18-40$ \\
\hline
\end{tabular}

Fase pada tubuh nyamuk disebut fase ekstrinsik karena terjadi diluar manusia atau fase seksual karena terjadi proses perkawinan antara mikrogamet (jantan) dan makrogamet (betina), fase akhir siklus ini berupa sporozoid, sehingga disebut juga siklus sporogoni, sedangkan pada tubuh manusia disebut fase intrinsik atau aseksual dimana fase akhir 
siklus ini berupa gamet sehingga disebut juga siklus gametogoni (Santjaka, 2013).

Nyamuk Anopheles dewasa adalah vektor penyebab malaria. Siklus hidup nyamuk Anopheles menurut (Arsin, 2012) yaitu;

a. Telur

Nyamuk betina meletakkan telurnya sebanyak 50-200 butir sekali bertelur. Telurtelur itu diletakkan di dalam air dan mengapung di tepi air. Telur tersebut tidak dapat bertahan di tempat yang kering dan dalam 2-3 hari akan menetas menjadi larva.

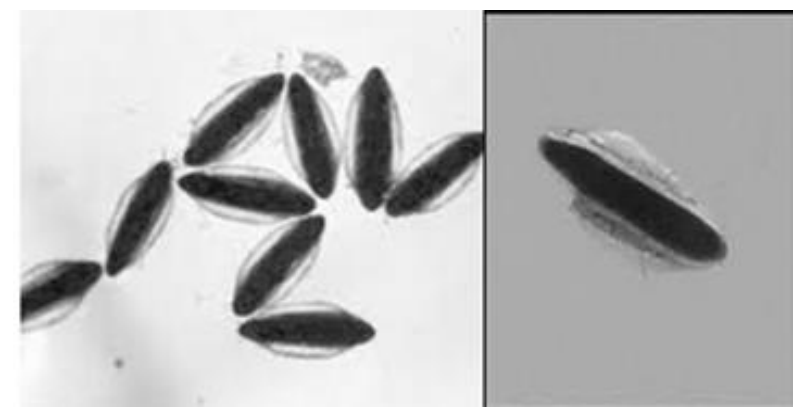

\section{b. Larva}

Gambar 1. Telur Nyamuk Anopheles

Larva nyamuk memiliki kepala dan mulut yang digunakan untuk mencari makan, sebuah torak dan sebuah perut. Mereka belum memiliki kaki. Dalam perbedaan nyamuk lainnya, larva Anopheles tidak mempunyai saluran pernafasan dan untuk posisi badan mereka sendiri sejajar dipermukaan air.

Larva berkembang melalui 4 tahap atau stadium, setelah larva mengalami metamorfisis menjadi kepompong. Disetiap akhir stadium larva berganti kulit, larva mengeluarkan exokeleton atau kulit ke pertumbuhan lebih lanjut.
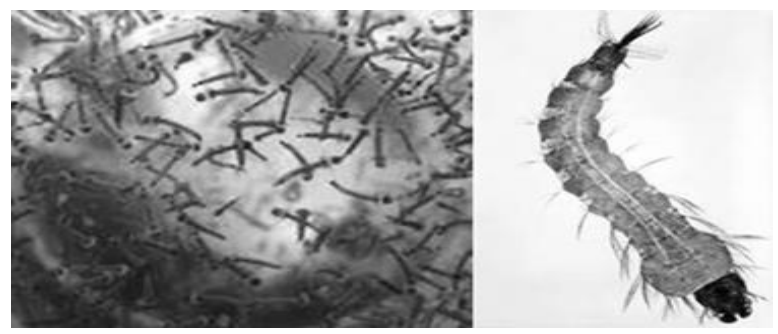

Gambar 2. Larva Nyamuk Anopheles

\section{c. Kepompong}

Kepompong terdapat dalam air dan tidak memerlukan makanan tetapi memerlukan udara. Pada kepompong belum ada perbedaan antara jantan dan betina. Kepompong menetas dalam 1-2 hari menjadi nyamuk, dan pada umumnya nyamuk jantan lebih dulu menetas daripada nyamuk betina. Lamanya dari telur berubah menjadi nyamuk dewasa bervariasi tergantung spesiesnya dan dipengaruhi oleh panasnya suhu. Nyamuk bisa berkembang dari telur ke nyamuk dewasa paling sedikit membutuhkan waktu 10-14 hari.

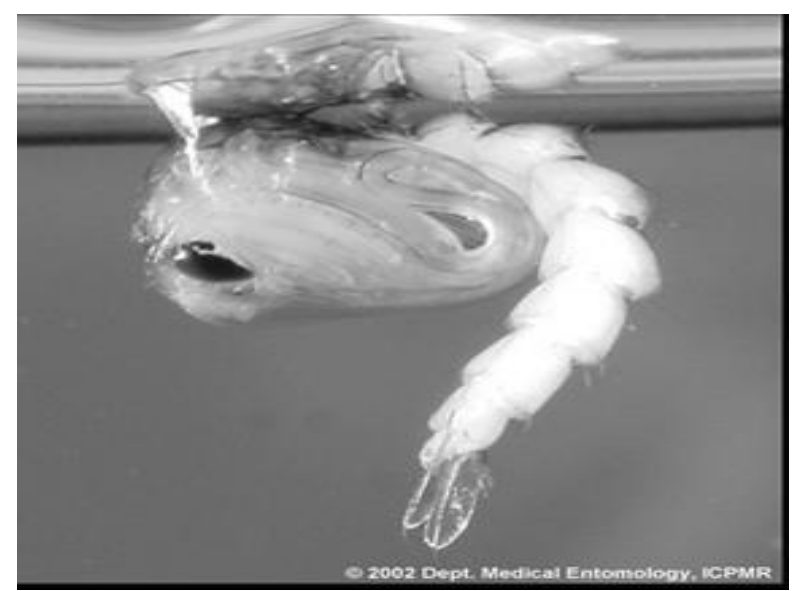

Gambar 3. Pupa Nyamuk Anopheles

d. Nyamuk dewasa

Semua nyamuk, khususnya Anopheles dewasa memiliki tubuh yang kecil dengan 3 bagian : kepala, torak dan abdomen (perut). Kepala nyamuk berfungsi untuk memperoleh informasi dan untuk makan. Pada kepala terdapat mata dan sepasang antena. Antena nyamuk sangat penting untuk mendeteksi bau host dari tempat perindukan dimana nyamuk betina meletakkan telurnya.

Perilaku vektor menurut (Santjaka, 2013) meliputi:

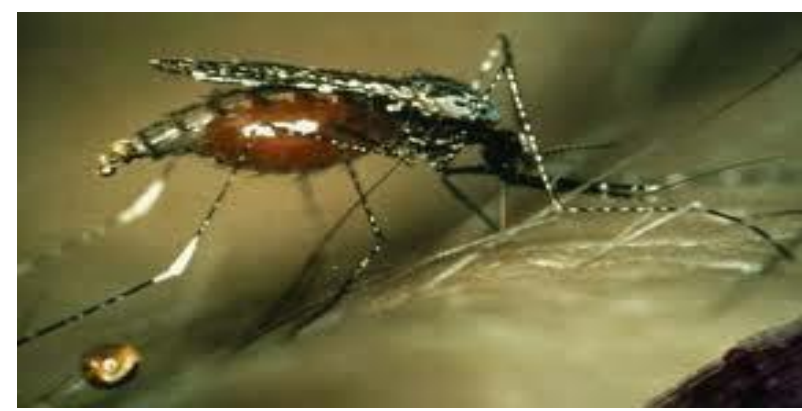

Gambar 4. Nyamuk Anopheles Dewasa

a. Perilaku mencari darah

Nyamuk betina yang mempunyai telur pada tingkat pertumbuhan saja yang aktif mencari darah. Nyamuk ini akan terbang 
menuju sumber rangsangan, rangsangan ini menjadi indikator keberadaan host kemudian baru menggigit hostnya.

b. Perilaku istirahat

Waktu istirahat nyamuk dapat dibedakan menjadi dua yaitu waktu istirahat sebenarnya, yaitu waktu dimana nyamuk istirahat sambil menunggu poses pematangan telur untuk kemudian siap bertelur breeding site, sedangkan istirahat sementara adalah waktu yang sebelum dan sesudah nyamuk mencari darah.

Tempat yang disenangi nyamuk untuk istirahat adalah tempat yang teduh dengan intensitas cahaya rendah, lembab, sedikit angin, gelap. Tempat seperti ini mirip ekosistem hutan dimana belukar ada dibawah pohon yang besar. Kanopi antara pohon dan keberadaan belukar menghalangi sinar matahari masuk menembus permukaan tanah, sehingga relatif lebih lembab.

\section{c. Perilaku Berkembang Biak}

Perkembangbiakan nyamuk selalu menggunakan media air genangan untuk melalui siklus aquanticnya, namun demikian kebutuhan akan air ini tidak harus banyak, hanya sedikit saja ada air, pasti digunakan nyamuk sebagai tempat perindukan. Nyamuk Anopheles $S p$ betina mempunyai kemampuan memilih tempat perindukan atau tempat perkembang biak sesuai dengan kesenangan dan kebutuhannya. Meskipun yang disukainya genangan yang kontak dengan tanah, namun jika hal tersebut tidak ditemukan, ternyata nyamuk Anopheles $S p$ juga akan menggunakan genangan air yang ada meskipun tidak bersentuhan langsung dengan tanah.

Jenis nyamuk Anopheles di Indonesia lebih dari 80 jenis sekitar 16 jenis yang menjadi nyamuk penyebaran malaria di Indonesia. Beberapa vektor mempunyai potensi untuk menularkan malaria, antara lain Anopheles aconitus, Anopheles farauti, Anopheles balanbacensis, Anopheles punclutatus, dan Anopheles barbirostis. Dan diantaranya yang dikemukakan oleh (Arsin, 2012) adalah :

\section{Anopheles aconitus}

Tempat perindukan larva pada persawahan dengan saluran irigasi tepi sungai pada musim kemarau, kolam ikan dengan tanaman rumput di tepinya. Perilaku nyamuk dewasa yakni zoofilik lebih banyak dari antropofilik menggigit di waktu senja sampai dini hari.

2. Anopheles farauti

Tempat perindukan larva pada kebun kangkung, kolam genangan air dalam perahu, genangan air hujan, rawa dan saluran air. Perilaku nyamuk dewasa yaitu antropofilik lebih banyak dari zoofilik menggigit di waktu malam tempat istirahat tetap didalam dan diluar rumah.

\section{Anopheles balanbacensis}

Tempat perindukan larva pada bekas roda yang tergenang air, bekas jejak kaki binatang pada tanah berlumpur yang berair, tepi sungai pada musim kemarau, kolam atau kali yang berbatu atau daerah pedalaman. Perilaku nyamuk dewasa yakni antrofilik lebih banyak dari zoofilik. Menggigit diwaktu malam hari, tempat istirahat tepat diluar rumah (di sekitar kandang ternak).

4. Anopheles punctulatus

Tempat perindukan larva pada air di tempat terbuka dan terkena langsung sinar matahari, pantai dalam musim penghujan dan tepi sungai. Perilaku nyamuk dewasa yakni antrofilik lebih banyak dari zoofilik, tempat istirahat tetap diluar rumah.

5. Anopheles barbirostis

Tempat perindukan larva pada kumpulan air yang permanen atau sementara, celah tanah bekas kaki binatang tambak ikan dan bekas galian di pantai. Perilaku nyamuk dewasa yakni antrofilik lebih banyak dari zoofilik, menggigit diwaktu malam tempat istirahatnya tetap diluar rumah.

6. Anopheles sundaicus

Tempat perindukan di pinggir pantai atau air payau menggigit di waktu malam hari tempat istirahatnya diluar rumah.

Untuk mengidentifikasi Anopheles sampai pada tingkatan spesies dengan cara melihat ciri morfologi dan dibandingkan dengan kunci identifikasi anopheles.

1. Morfologi Sub Genus Anopheles

Merupakan Subgenus anopheles jika costa dan urat 1 sayap terdapat tiga noda pucat atau kurang. Setelah itu diamati pada 
bagian palpusnya. Jika terdapat 4 gelang pucat maka menuju kunci identifikasi Anopheles hyrcanus group. Jika pada palpus tidak terdapat belang pucat maka diamati pada bagian sternit abdomen ketujuh. Jika terdapat kumpulan sisik atau sikat gelap maka termasuk Anopheles barbirostris group, dan Jika sternit abdomen ketujuh tidak terdapat kumpulan sisik (sikat gelap) maka termasuk Anopheles umbrosus group.

2. Morfologi Anopheles hyrcanus Group Apabila gelang pucat, tarsus kaki belakang sempit dan apabila tanda gelap pada pangkal urat 5 panjang, dan jumbai pucat pada sayap sempi maka termasuk Anopheles lesteri paraliae. Jika tanda gelap pangkal urat ke-5 pendek dan jumbai pucat pada ujung sayap lebar maka termasuk Anopheles sinensis (ujung urat 1 gelap dan jika ada jumbai pucat pada urat 5.2) dan merupakan Anopheles crawfordi (apabila ujung urat 1 pucat dan tidak ada jumbai pucat pada urat 5.2). Apabila gelang pucat, tarsus kaki belakang : sedang atau sangat lebar dan Apabila tanda gelap pada pangkal urat 5 pendek, dan ada jumbai pucat urat 5.2 merupakan Anopheles nitidus /indiensis, sedangkan tanda gelap pangkal urat 5 panjang maka menuju identifikasi selanjutnya. Apabila terdapat gelang pucat tarsus 3 kaki belakang $\geq$ tarsus 4 , tidak ada jumbai pucat pada urat 5.2 merupakan Anopheles argyropus. Apabila gelang pucat tarsus 3 kaki belakang $>$ tarsus 5, tidak ada jumbai pucat pada urat 5.2 merupakan Anopheles peditaenatus. jika gelang pucat tarsus 3 kaki belakang < tarsus 5, ada jumbai pucat pada urat 5.2 merupakan Anopheles nigerrimus.

3. Morfologi Sub genus Cellia

Termasuk kedalam sub genus Cellia jika costa dan urat 1 sayap terdapat empat noda pucat atau lebih. Diamati pada bagian kakinya, jika kaki tidak berbercak bintikbintik pucat atau tidak belang, kemudian diamati pada bagian tarsus 5 kaki belakang maka menuju kunci selanjutnya. Jika tarsus 5 kaki belakang gelap maka selanjutnya diamati pada bagian ujung probosisnya maka menuju kunci selanjutnya, apabila terdapat sedikit bagian pucat maka termasuk Anopheles vagus, sedangkan jika probosis gelap, gelang pucat sub apical palpus $\geq$ gelang sub apical maka termasuk Anopheles indefinitus. Jika probosis gelap, gelang pucat sub apical palpus $\leq 1 / 3$ gelang sub apical gelap maka termasuk Anopheles subpictus. Apabila setengah ujung proboscis pucat dan terdapat jumbai pucat pada urat sayap no. 6 maka termasuk Anopheles aconitus, sedangkan Jika setengah ujung proboscis bagian bawah pucat, tidak ada jumbai pucat pada ujung urat sayap no. 6 maka termasuk Anopheles minimus. Apabila jika tarsus 5 kaki belakang seluruhnya pucat maka termasuk Anopheles karwari, dan Jika tarsus 3, 4 dan 5 kaki belakang pucat maka termasuk pada Anopheles annularis. Apabila kaki berbercak bintik-bintik pucat atau belang maka diamati pada bagian persambungan tibia-tarsusnya, jika persambungan tibiatarsus kaki belakang terdapat gelang pucat lebar maka menuju kunci identifikasi Anopheles leucosphyrus group, namun jika persambungan tibia-tarsus kaki belakang tidak terdapat gelang pucat lebar maka diamati lagi bagian palpusnya kemudian jika palpus dengan 3 cincin pucat dan proboscis seluruhnya gelap maka diamati lagi pada bagian tarsus 5 kaki belakang sebagian atau seluruhnya gelap maka termasuk Anopheles sundaicus. Jika tarsus 5 kaki belakang pucat maka termasuk Anopheles maculatus. Apabila palpus dengan 4 cincin pucat atau lebih setengah proboscis bagian ujung pucat maka diamati pada bagian sternit abdomen II-IV jika terdapat kumpulan sisik (sikat) gelam maka termasuk Anopheles kochi dan Jika sternit abdomen II-IV tidak terdapat kumpulan sisik (sikat gelap) maka termasuk Anopheles tessellatus.

4. Morfologi leucospyrus group Apabila Proboscis lebih panjang dari pada palpus maka Presector gelap (urat 1 sayap) ada 1 atau lebih tanda pucat maka termasuk Anopheles Sulawesi. Apabila presector gelap (urat 1 sayap) tidak ada tanda pucat dan gelang pucat ujung palpus sangat sempit maka termasuk Anopheles hacker. 
Jika gelang pucat ujung palpus lebar $\geq$ preapical gelap maka menuju kunci selanjutnya pada preapical gelap urat 1 sayap ada 1 tanda pucat dan pangkal tarsus 4 kaki belakang ada gelang pucat lebar maka termasuk Anopheles elegans dan apabila pada preapical gelap urat 1 sayap ada 2 atau lebih tanda pucat dan pangkal tarsus 4 kaki belakang ada gelang pucat sempit/ tidak ada maka termasuk Anopheles pujutensis. Jika proboscis sama / lebih pendek daripada palpus Pangkal presector gelap urat 1 sayap, memanjang, melebihi gelap humeral pada costa maka termasuk Anopheles leucosphyrus dan Presector gelap urat 1 sayap sama panjang dengan tanda gelap humeral pada costa maka termasuk Anopheles balabacensis. (Nuryadi, 2013)

Pencegahan malaria secara garis besar mencakup tiga aspek sebagai berikut yang di kemukakan (Arsin, 2012):

1. Mengurangi pengandung gametosit yang merupakan sumber infeksi (reservoar). Hal tersebut dapat dicegah dengan jalan mengobati penderita malaria akut dengan obat yang efektif terhadap fase awal dari siklus eritrosit aseksual sehingga gametosit tidak sempat terbentuk didalam darah penderita. Selain itu, jika gametosit telah terbentuk dapat dipakai jenis obat yang secara spesifik dapat membunuh gametosit (obat gametosida).

2. Memberantas nyamuk sebagai vektor malaria Memberantas nyamuk dapat dilakukan dengan menghilangkan tempattempat perindukan nyamuk, membunuh larva atau jentik dan membunuh nyamuk dewasa. Pengendalian tempat perindukan dapat dilakukan dengan menyingkirkan tumbuhan air yang menghalangi aliran air, melancarkan aliran saluran air dan menimbun lubang-lubang yang mengandung air.

3. Melindungi orang yang rentan dan berisiko terinfeksi malaria.

Secara prinsip upaya ini dikerjakan dengan cara sebagai berikut:

a. Mencegah gigitan nyamuk

b. Memberikan obat-obat untuk mencegah penularan malaria c. Memberi vaksinasi (belum diterapkan secara luas dan masih dalam tahap riset atau percobaan di lapangan).

\section{BAHAN DAN METODE}

Penelitian ini merupakan penelitian deskriptif untuk menggambarkan keragaman dan kepadatan (Man Biting Rate) nyamuk Anopheles di Desa Ranoketang Tua Kecamatan Amurang Kabupaten Minahasa Selatan. Populasi dalam penelitian ini adalah nyamuk Anopheles di Desa Ranoketang Tua Kecamatan Amurang Kabupaten Minahasa Selatan.

Sampel dalam penelitian ini nyamuk Anopheles yang tertangkap melalui metode umpan orang dalam (UOD) dan umpan orang luar (UOL) yang diidentifikasi spesiesnya dan dihitung Man Bitting Rate (Jumlah Nyamuk Mengigit per orang per malam) dengan rumus

MBR adalah jumlah nyamuk yang tertangkap per spesies / jumlah perangkap X waktu penangkapan (Jam)

Data hasil penelitian dianalisis secara deskripitf, berupa angka kepadatan dan jenis spesies disajikan dalam bentuk tabel dan grafik kemudian dinarasikan dan disimpulkan.

\section{HASIL}

\section{Gambaran Umum Lokasi Penelitian}

Desa Ranoketang Tua merupakan salah satu Desa yang berada dalam wilayah administratif Kecamatan Amurang, Kabupaten Minahasa Selatan. Desa Ranoketang Tua merupakan daerah endemis malaria dan sering dilakukan kegiatan penelitian dan pengendalian malaria oleh Badan Penelitian Dan Pengembangan Kementerian Kesehatan RI seperti Survei Longitudinal Vektor Malaria dan penyemprotan insektisida dengan metode Indoor Residual Spraying (IRS) serta pembagian kelambu berinsektisida. Secara geografis Desa Ranoketang Tua merupakan daerah perkebunan kelapa, berbukit-bukit serta banyak terdapat kolam ikan dengan ketinggian antara kira-kira $275 \mathrm{~m}$.di atas permukaan laut. 


\begin{tabular}{|c|c|c|c|c|c|}
\hline \multirow[t]{3}{*}{ No } & \multirow[t]{3}{*}{$\begin{array}{c}\text { Spesies } \\
\text { Anopheles }\end{array}$} & \multirow{2}{*}{\multicolumn{2}{|c|}{$\begin{array}{l}\text { Penangkapan } \\
\text { Malam Hari }\end{array}$}} & \multirow[t]{3}{*}{$\begin{array}{c}\text { Total } \\
\text { Nyamuk }\end{array}$} & \multirow[t]{3}{*}{ MBR } \\
\hline & & & & & \\
\hline & & $\begin{array}{l}\text { Dalam } \\
\text { (UOD) }\end{array}$ & $\begin{array}{c}\text { Luar } \\
\text { (UOL) }\end{array}$ & & \\
\hline 1. & An. barbirostris & 113 & 279 & 392 & 49 \\
\hline 2. & An. tessellatus & 1 & - & 1 & 0,125 \\
\hline 3. & An. flavirostris & 5 & 25 & 30 & 3,75 \\
\hline & Total & 119 & 304 & 423 & \\
\hline
\end{tabular}

2. Hasil Survei Entomologi

a. Keragaman Anopheles sp.

Penangkapan nyamuk Anopheles sp pada malam hari dilaksanakan pada tanggal 22-24 Juni 2019 dan dilakukan 2 (dua) kali pengulangan dengan metode umpan orang dalam (UOD) dan umpan orang luar (UOL), Jumlah penangkap terdiri dari 3 orang di dalam rumah dan 3 orang penangkap di luar rumah. Waktu penangkapan selama 40 menit untuk setiap jam penangkapan dan dilakukan pada jam 18.00 sampai jam 06.00 pagi. Nyamuk Anopheles yang tertangkap kemudian diidentifikasi menggunakan mikroskop untuk menentukan spesiesnya.

Jumlah nyamuk Anopheles yang tertangkap pada penangkapan malam hari di Desa Ranoketang Tua seluruhnya 423 ekor. Berdasarkan hasil identifikasi dengan menggunakan acauan, O'Connor dan Soepanto (1979) dalam Kemenkes RI (2016) dari hasil penangkapan nyamuk dewasa ditemukan 3 (tiga) spesies Anopheles yaitu: An. barbirostis, An. tessellatus dan An. flavirostris (Tabel 2). Tabel 2. Hasil Tangkapan Nyamuk Anopheles Pada Malam Hari Di Desa Ranoketang Tua

\begin{tabular}{ccccc}
\hline \multirow{2}{*}{ No } & \multirow{2}{*}{$\begin{array}{c}\text { Spesies } \\
\text { Anopheles }\end{array}$} & \multicolumn{2}{c}{$\begin{array}{c}\text { Jumlah Nyamuk (\%) per } \\
\text { Penangkapan }\end{array}$} & \multirow{2}{*}{ Total (\%) } \\
\cline { 3 - 4 } & & Penangkapan I Penangkapan II & \\
\hline \multirow{2}{*}{1} & \multirow{2}{*}{ An. barbirostris } & 230 & 162 & 392 \\
& & $(58,67 \%)$ & $(41,32 \%)$ & $(92,67 \%)$ \\
2 & \multirow{2}{*}{ An. tessellatus } & $(100 \%)$ & - & 1 \\
& & 19 & 11 & $(0,23 \%)$ \\
3 & \multirow{2}{*}{ An. flavirostris } & $(63,33 \%)$ & $(36,67 \%)$ & $(7,1 \%)$ \\
\hline \multirow{2}{*}{} & \multirow{2}{*}{ Jumlah } & 250 & 173 & 423 \\
& & $(59,1 \%)$ & $(40,9 \%)$ & $(100 \%)$ \\
\hline
\end{tabular}

b. Kepadatan

Hasil penangkapan pada malam hari dari nyamuk Anopheles sp di Desa Ranoketang Tua pada Tabel 1 terlihat paling dominan (banyak tertangkap) secara berurutan yaitu An. barbirostis (92,67\%), An. flavirostris $(7,1 \%)$ dan An. tessellatus $(0,23 \%)$. Berdasarkan hari penangkapan jumlah nyamuk
Anopheles terbanyak yaitu pada penangkapan pertama $(59,1 \%)$.

Tabel 3. Kepadatan Nyamuk Anopheles Di Desa Ranoketang Tua

Nyamuk Anopheles yang paling banyak tertangkap adalah dengan metode UOL dengan total nyamuk tertangkap 304 ekor dan terendah adalah nyamuk yang tertangkap dengan metode umpan orang dalam (UOD) yaitu 119 ekor.

Spesies Anopheles tertangkap sebagian besar adalah $A n$. barbirostris dengan jumlah 392 ekor dan terendah yaitu An. tessellatus dengan jumlah tertangkap 1 ekor, dari 3 (tiga) spesies Anopheles yang ditemukan terdapat 1 spesies yang sangat berperan dalam penularan penyakit malaria di Desa Ranoketang Tua yaitu An. Barbirostris.

\section{PEMBAHASAN}

1. Keragaman Spesies Nyamuk Anopheles.

Nyamuk Anopheles yang tertangkap pada malam hari di Desa Ranoketang Tua Kecamatan Amurang Kabupaten Minahasa Selatan ada 3 (tiga) spesies yaitu: $A n$. barbirostris, An. tessellatus, dan An. flavirostris. Ketiga jenis Anopheles ini biasanya ditemukan di Indonesia, penelitian yang dilakukan oleh Marpaung (2006) didaerah Sukabumi juga menemukan ketiga jenis nyamuk Anopheles ini dan penelitian dari Jastal (2007) yang menemukan ketiga spesies ini di daerah Sulawesi Tengah,

Hasil penelitian Mardiana, et al. (2005) hasil penangkapan malam hari di Desa Buaran dengan kondisi geografis berupa dataran sedikit berbukit dengan persawahan diperoleh 6 (enam) spesies. Beda dengan penelitian ini yaitu tidak ditemukan spesies An. Vagus, An. aconitus dan An. maculatus.

Penangkapan nyamuk malam hari metode UOD dan UOL, spesies nyamuk yang paling banyak tertangkap baik di dalam maupun di luar rumah yaitu $A n$. barbirostris dibandingkan dengan spesies lainnya. Spesies ini dapat dikatakan sebagai tersangka vektor malaria di Desa Ranoketang Tua Kecamatan Amurang 
Kabupaten Minahasa Selatan. Nyamuk Anopheles sp dapat diduga sebagai vektor malaria apabila memenuhi persyaratan antara lain kontak dengan manusia cukup tinggi, merupakan spesies dominan dan di tempat lain ternyata spesies tersebut telah dikonfirmasi sebagai vektor (Munif \& Imron, 2010).

Anopheles barbirostris adalah vektor yang penyebarannya berada dilokasi pedalaman, dan biasanya larvanya berada dikolam kecil rawa dan sawah (hoedojo, 1989; zulhasril,2001), Ranoketang Tua adalah wilayah yang akan masuk kategori pedalaman dan di desa ini terdapat kolam dan sawah sehingga menjadi tempat yang ideal untuk habitat hidup dari nyamuk ini. $A n$. barbirostris biasanya berasosiasi dengan An. Aitkenii, An.sinensis, An Philippinensis dan An.Annularis (Ompusunggu S dkk,1994), tapi didesa Ranoketang Tua tidak ditemukan salah satu dari asosiasi nyamuk An. barbirostris ini. (Mandagie dkk, 2015)

Anopheles flavirostris adalah nyamuk yang didapatkan kedua terbanyak dalam penangkapan malam hari. Nyamuk ini biasanya berada di kaki gunung, di pulau Jawa biasa ditemukan di daerah hutan atau juga di kolam (Mandagie dkk, 2015), Desa Ranoketang Tua adalah salah satu desa yang berada dikaki gunung Soputan dan kawasannya berada di kawasan hutan dan memiliki kolam dengan keadaan seperti ini membuat Desa Ranoketang Tua menjadi tempat yang strategis untuk menjadi tempat habitat dari nyauk An.flavirostris.

2. Kepadatan Nyamuk Anopheles sp

Nyamuk Anopheles yang paling aktif menggigit selama 2 kali penangkapan malam hari metode umpan orang dalam (UOD) dan umpan orang luar (UOL) adalah jenis An. barbirostris dengan jumlah 392 ekor, MBR 49 ekor nyamuk menggigit per orang per malam nyamuk Anopheles yang aktif menggigit berikutnya adalah An. flavirostris dengan jumlah gigitan 30 ekor, MBR 3,75 ekor nyamuk menggigit per orang per malam dan yang paling sedikit aktivitas menggigitnya yaitu An. tessellatus dengan jumlah 1 ekor 0,125 ekor nyamuk menggigit per orang per malam .

Sebagian besar nyamuk Anopheles sp mempunyai aktivitas menggigit pada malam hari dan mempunyai fluktuasi pada jam-jam tertentu. Berdasarkan waktu menggigit spesies nyamuk Anopheles mempunyai aktivitas pada permulaan sesudah matahari terbenam sampai dengan matahari terbit (Depkes RI, 2001).

Sebagian besar spesies nyamuk Anopheles mempunyai dua puncak gigitan pada malam hari yang berbeda diantara satu spesies dan spesies lainnya. Keadaan ini dapat berubah karena adanya pengaruh suhu, kelembapan udara dan kecepatan angin, sehingga dapat menyebabkan bertambah atau berkurangnya kehadiran nyamuk Anopheles di suatu tempat (Depkes RI, 2001).

Nyamuk An. barbirostris merupakan spesies yang ditemukan paling dominan di lokasi penelitian. Berdasarkan aktivitas menggigit lebih suka menggigit di luar rumah atau bersifat eksofagik, hal ini terbukti dengan ditemukan $A n$. barbirostris aktif menggigit di luar rumah (sebanyak 279 nyamuk) hampir sepanjang malam dengan kepadatan tertinggi pada jam 21.00-22.00, tetapi juga ditemukan menggigit di dalam rumah dengan jumlah lebih rendah yaitu sebanyak 113 nyamuk. dengan puncak aktivitas menggigit tertinggi di dalam rumah yaitu pada jam 01.00-02.00. Dalam kisaran waktu tersebut sebagian penduduk di tempat penelitian masih melakukan aktivitas baik di dalam maupun di luar rumah. Hasil penelitian ini berbeda dengan penelitian yang dilakukan oleh Limrat, et al.(2001) yang menyatakan puncak kepadatan menggigit $A n$. barbirostris terjadi antara jam 22.00-24.00.

Nyamuk An. flavirostris merupakan spesies dominan kedua setelah $A n$. barbirostris di lokasi penelitian. Hasil penelitian menunujukkan Puncak aktivitas menggigit $A n$. flavirostris terjadi pada jam $18.00-19.00,20.00-21.00,23.00-24.00$ 
dam 04.00-05.00. Hal ini sejalan dengan penelitian (Warrell \& Gilles, 2002) yang menyatakan bahwa perilaku menggigit nyamuk Anopheles mulai senja hingga tengah malam.

Nyamuk Anopheles sp dapat dibedakan berdasarkan tempat menggigit ada yang eksofagik dan endofagik. Nyamuk yang eksofagik merupakan nyamuk yang banyak menggigit di luar rumah, tetapi dapat juga menggigit di dalam rumah namun frekuensinya kecil, sedangkan nyamuk endofagik adalah nyamuk yang dominan menggigit di dalam rumah, tetapi dapat juga menggigit di luar rumah namun frekuensinya kecil (Depkes RI, 2001). An. tessellatus dalam penelitian ini kepadatannya paling sedikit. Menurut Jastal dkk (2007), An. tessellatus memiliki sifat zoofagik sehingga walaupun jumlahnya di lokasi penelitian cukup banyak tapi An. tessellatus lebih cenderung akan mencari darah hewan ketimbang darah manusia.

Hasil penelitian memperlihatkan bahwa nyamuk Anopheles sp di daerah penelitian pada umumnya banyak menggigit orang di luar rumah dibandingkan dengan yang menggigit di dalam rumah atau bisa dikatakan spesies Anopheles sp di daerah penelitian lebih bersifat eksofagik dibandingkan endofagik. Hasil penelitian ini sejalan dengan hasil penelitian Munif, et al. (2007) tentang bionomik Anopheles sp di daerah endemis malaria, Kecamatan Lengkong, Kabupaten Sukabumi yang menyatakan nyamuk Anopheles sp pada umumnya banyak menggigit di luar rumah dibandingkan dengan menggigit di dalam rumah.

\section{KESIMPULAN}

1. Ditemukan 3 (tiga) spesies Anopheles di Desa Ranoketang Tua yaitu An. Barbirostis, An. tesselatus dan An. flavirostris.

2. Kepadatan nyamuk Anopheles sp di Desa Ranoketang Tua tidak sesuai nilai baku mutu : Nyamuk An. barbirostris MBR 49 ekor nyamuk menggigit per orang per malam, Nyamuk An. flavirostris MBR 3,75 ekor nyamuk menggigit per orang per malam dan nyamuk An. tesselatus MBR 0,125 ekor nyamuk menggigit per orang per malam.

\section{SARAN}

1. Untuk Masyarakat Menggunakan kelambu berisektisida agar dapat terhindar dari gigitan nyamuk Anopheles sp dan dapat mengurangi populasi dari nyamuk Anopheles sp, juga disarankan menggunakan obat nyamuk atau reppelant pada saat tidur dan menggunakan pakaian lengan panjang jika melakukan aktivitas di luar rumah pada malam hari.

2. Untuk Dinas Kesehatan Kabupaten.

a. Perlu dilakukan secara rutin survei entomologi untuk mengetahui bionomik dari nyamuk Anopheles $s p$ karena setiap daerah memilki lokal spesifik yang berbeda, sehingga mempermudah dalam penentuan metode atau cara untuk pengendalian nyamuk Anopheles sp.

b. Perlu ditingkatkan program penyuluhan kepada masyarakat tentang bahaya dari nyamuk Anopheles sp dan cara pengendaliannya.

\section{UCAPAN TERIMA KASIH}

Ucapan terima kasih disampaikan kepada enumerator yang telah membantu dalam pengumpulan data sehingga penelitian dapat diselesaikan sesuai dengan waktu yang ditetapkan.

\section{DAFTAR PUSTAKA}

1. Arsin A. A. (2012). Malaria di Indonesia (Tinjauan aspek epidemiologi) Masagena Press, Makassar.

2. Depkes RI, 2001, Pedoman Ekologi dan Aspek Perilaku Vektor, Ditjen PPM \& PL Depkes RI, Jakarta.

Depkes RI, 2007, Vektor Malaria di Indonesia, Ditjen PP \& PL Depkes RI, Jakarta.

3. Depkes R.I. (2008). Pedoman Penatalaksanaan Kasus Malaria di Indonesia. Di akses Tanggal 5 Januari 2016.

4. Ginandjar P., Hidayati., Gambiro (2005). Faktor Lingkungan Yang Berkaitan Dengan Kejadian Malaria. Jurnal, 4 (1). Diakses tanggal 30 juni 2016. 
5. Harmendo (2008). Faktor Resiko Kejadian Malaria. Universitas Diponegoro, Semarang. Di akses tanggal 4 januari 2016.

6. Marpaung, F, (2006), Penyusunan Model Spasial Prediksi Lingkungan sebaran Malaria, Tesis, IPB, Bandung

7. Imbiri J.K., Suhartono., Nurjazuli. (2012). Analisis Faktor Resiko Malaria. Jurnal, 11(2). Diakses tanggal 30 juni 2016.

8. Jastal, Labatjo Y. Maksud M. (2007), Bionomik Nyamuk Anopheles Sp pada daerah perkembunan coklat didesa Malino kecamatan Marawola Kabupaten Donggala Sulawesi Tengah, Jurnal Vektor Penyakit,Litbangkes, Jakarta Vol. 1 No. 1

9. Kemenkes R.I. (2015). Data dan Infomasi tahun 2014 (Profil kesehatan Indonesia) Di akses Tanggal 12 Januari 2016.

10. Kemenkes RI. (2017). Peraturan Menteri Kesehatan Republik Indonesia Nomor 50 Tahun 2017 Tentang Standar Baku Mutu Kesehatan Lingkungan Dan Persyaratan Kesehatan Untuk Vektor Dan Binatang Pembawa Penyakit Serta Pengendaliannya. Jakarta.

11. Limrat, D., Rojruthai, B., Apiwathnason, C., Samsung, Y., \& Prommongkol, S., 2001, Anopheles barbirostris/campestris as a Probable Vektor os Malaria in Aranyaprathet, $\mathrm{Sa}$ Kaeo Province. Southeast Asian J. Trop Med Publich Health.,32(4) : 739 - 44.

12. Mandagi C, Masalamate P.R, Rompis A.H, (2015). Analisis Bionomik Nyamuk
Anopheles Di Desa Ranoketang Tua Kecamatan Amuran Kabupaten Minahasa Selatan, Jurnal Kesmas Unsrat Manado. Vol. 4 No. 1

13. Mardiana,, Yusniar., Aminah, A.N., \& Yunanto, 2005, Fauna dan Tempat Perkembangbiakan Potensial Nyamuk Anopheles spp di Kecamatan Mayong Kabupaten Jepara Jawa Tengah, Media Litbang Kesehatan., 15 (2).

14. Munif, A., \& Imron, M., 2010, Panduan Pengamatan Nyamuk Vektor Malaria, Jakarta, Penerbit CV. Sagung Seto.

15. Munif, A., Sudomo, M., \& Soekirno, 2007, Bionomik Anopheles spp di daerah endemis malaria di Kecamatan Lengkong, Kabupaten Sukabumi, Buletin Penelitian Kesehatan., 35(2): 57 - 80.

16. Nuryadi, M.M. 2013. Identifikasi Morfologi : Spesies Vektor Malaria Di B2P2VRP Salatiga. Proposal Kegiatan Magang. Universitas Negeri Jember

17. Provinsi Sulut (2017). Buku Saku Profil Kesehatan Provinsi Sulawesi Utara. Di akses Tanggal 08 Mei 2018.

18. Puskesmas Amurang (2018). Register Penderita Malaria di Unit Pelayanan Kesehatan.

19. Santjaka A. (2013). Malaria (Pendekatan Model Kausalitas). Nuha medika, Yogyakarta.

20. Soedarto (2012) Protozologi Kedokteran. CV Karya Putra Darwati, Bandung.

21. Warrell, D.A., \& Gilles H.M., 2002, Essential Malariology Fourth Edition, London, New York, New Delhi, Arnold. 